\title{
Significance of Cultural Heritage Assets in the Definition of Urban Morphology a case of Egba- Ake in South-West Nigeria
}

Titilayo ANIFOWOSE, Department of Architecture Faculty of Environmental Science University of Lagos Akoka, Nigeria

Titilayo ANIFOWOSE, Department of Architecture Faculty of Environmental Science University of Lagos Akoka, Nigeria

\begin{abstract}
This study defined morphological importance of cultural heritage assets and formation of Egba-Ake town. Cultural heritages include man's physical imaginative products which can be touched and seen include buildings, crafts, tools, ivory, cowries, paintings, textiles, pestles, mortars, food, wooden objects, tombs \& grave goods, temples, dresses, pottery \& potsherd pavements, monuments, books and artifacts. Morphology are factors that influence city/community formation which are determined by synthetic and natural determinants. Cultural heritage assets are whatever is valued by people today that was also cherished by former generations. This research explored the importance of cultural heritage assets in relation to urban fabrics formation of Egba-Ake. Qualitative method was adopted in this study, in-depth interviews and personal observation was used for data collection while Nvivo words tree and satellite imagery was used to analyze collected data. Ake's palace and ltoku market is located at the center around which the Egba-Ake evolved. Ake's Palace (political and cultural hub of the town) and Itoku market (the economic heritage of the town) was used to preserve various aspects of Egba-Ake cultural heritage. Ela festival (new yam festival) is annually celebrated cultural activity in Egba-Ake. This finding is relevant to policy makers as it allows the support of potential common structures for heritage administration in Egba-Ake. Effect of heritage in EgbaAke morphology is the new palace of Alake (the cultural ruler) of Egba-Ake were renovated and new once built a few years ago with modern architectural designs, furniture and fittings. This has made the Alake's Palace to meet 'international standards'. Social amenities and infrastructures like electricity supply, water systems, hospitals, good roads, administrative offices, schools; communication networks, etc. are now a major feature in Egba-Ake town. Further studies will enhance the implementation issues which may arise from the creation of a framework for cultural heritage management, with emphasis on risk management and risk reduction of cultural heritage.
\end{abstract}

\section{Keywords}

Urban cultural heritage, Cultural activities, Egba-Ake morphology, Identity

\subsection{Introduction}

This research paper is an academic contribution to the department of architecture relating cultural heritage assets in the form of building settings and artifacts to city formation. This research paper was self funded.

Cultural heritage is the term given here to 'treasure features of our environments which we seek to protect 
from the effects of development and deterioration' (Davison, 1991). Cultural heritage assets are the expressions of people's collaboration with their surroundings. They define our culture in space and time: they are part of the setting that makes us human (Aplin, 2002). As the relics of physical culture pre-date written records, cultural heritage assets are often the only remnants of people's historical routes or traditional events (Hutt, Blanco \& Varmer, 1999). Once demolished, they cannot be regenerated, reproduced or restored (Pearson \& Sullivan, 1995). Jokilehto (1986) stated that cultural heritage is a treasure for the study of architecture as essential documents to enlighten the history of various people forever. Nevertheless, cultural heritage is very essential in nurturing the quality of life in all societies. It originated from an historic meaning and evidence that the cultural constituents transmit from the past to the present and the future (Fallahi, 2008). Cultural heritage denotes a shared bond, our belonging to a community and they give us a better understanding about who we are and where we come from, as well as our history, identity, link to the past, the present, and the future. Feather (2006) stated that the motivating force behind all definitions of cultural heritage is a human formation projected to inform. Culture is made up of the customs, traditions, beliefs, behavior, and dress, works of art and craft, approach to life. The latter varies from society to society that cultural values are relative (Edo, 2005). Religion is the focal point of Yoruba culture according to Idowu (1970). Famuyiwa (1992) stated that festivals and religious activities play vital roles and that is why consent classifies himself through ritualizedsymbol of the events that inform people about his identity. Contribution to the rites of local traditional deities accepted in such a community becomes a strong means of identity establishment and yields a mutual mystical consciousness (Ogungbile, 1998).

Adedimeji (2009) stated that culture symbolizes the people's means of life, norms, values, morals, ethos, ethics, and customs. He identified different principles of cultural heritage in any society from thus persistent. First culture functions as intuition that reflects how people distinguish themselves and understand their environment. Secondly culture acts as a spring of motivation. Finally, culture defines the production and consumption attitude of people. Culture and identity form and give positive meanings to some places and to the urban space as a whole (Madden, 2012). Built environment and culture are closely related. In a certain way, the design of the built environment carries and promotes culture. The linking element between the environment and culture is the urban morphology (O"Neil, 2006). When urban fabrics are successful, they will increase chances to participate in communal activity (Carr et al., 1993). Thus, cultural activities and events are a main purpose for gathering people; they are the link between the space and people. Cultural heritage is considered as a combination of several elements, which are: human processes, activities and urban elements, (Abdel Tawab, 2014). Cultural heritage assets are whatever that is treasured by people today that was also valued by former generations. Heritage is what has been established as gifts from those who came before us. Heritage is our inheritance of land, language, 
ecosystems, knowledge, and culture. It is therefore important to state that man cannot survive without the construction and use of artifacts" (Ogundele, 2014). Griffiths, (2006) stated that culture can be used to improve social and economic goals of the city. Pejovic, (2009) discovered that urban arts festivals have boomed to a greater height than any other cultural activities. In the last 20 years, innumerable arts festivals have been presented in the interest of revitalizing urban economies, regenerating entire cities or city districts, and introducing or repositioning cities on the ever more competitive global stage (Shin, 2004; Yardimci, 2007). This study explored the importance of cultural heritage assets in the definition of urban morphology at Egba-Ake.The selected case study is Egba-Ake palace square and Itoku market in Egba-Ake town, Abeokuta. Egba-Ake town evolved from Ake palace square in 1830 in accordance with Yoruba indigenous urban architecture where the city evolved from the palace square. Ake urban fabrics were formed based on Yoruba indigenous affinity links and belief that clans should live together in compounds called Agbo-ile. Egba-Ake is located in Abeokuta South Local Government Area of Ogun State, Nigeria. It is the local government headquarters of Ake Abeokuta7 $\hat{A}^{\circ} 0900 " \mathrm{~N}$ latitude, $3 \hat{A}^{\circ} 2100$ "E longitude. (Figure1) Egba-Ake has grown phenomenally in the past fourteen years in terms of residential development and human population. According to the National Population Commission (2006) Census, the population of Abeokuta is 449,088. Ake is the administrative hub of Egba-Ake where Ake people are governed traditionally. The palace is also the seat of Abeokuta paramount ruler while Itoku market is the economic heritage of the town that is identified with Adire fabrics.

Figure 1: Map of South-West state in Nigeria showing Abeokuta south where Egba-Ake is located

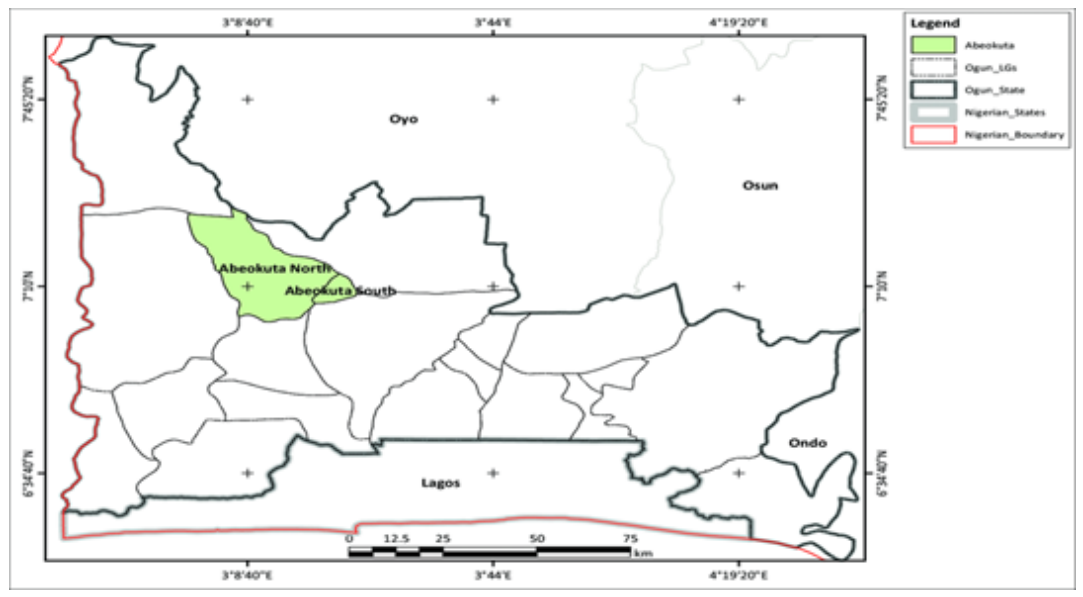

\subsection{Conceptual Review}


Thurley, (2005) an architectural historian, proposed a heritage diagram, which gives us an idea of how we can make the past part of our future (Figure2.0).

Figure 2. The Heritage Cycle diagram (Source: Thurley, 2005)

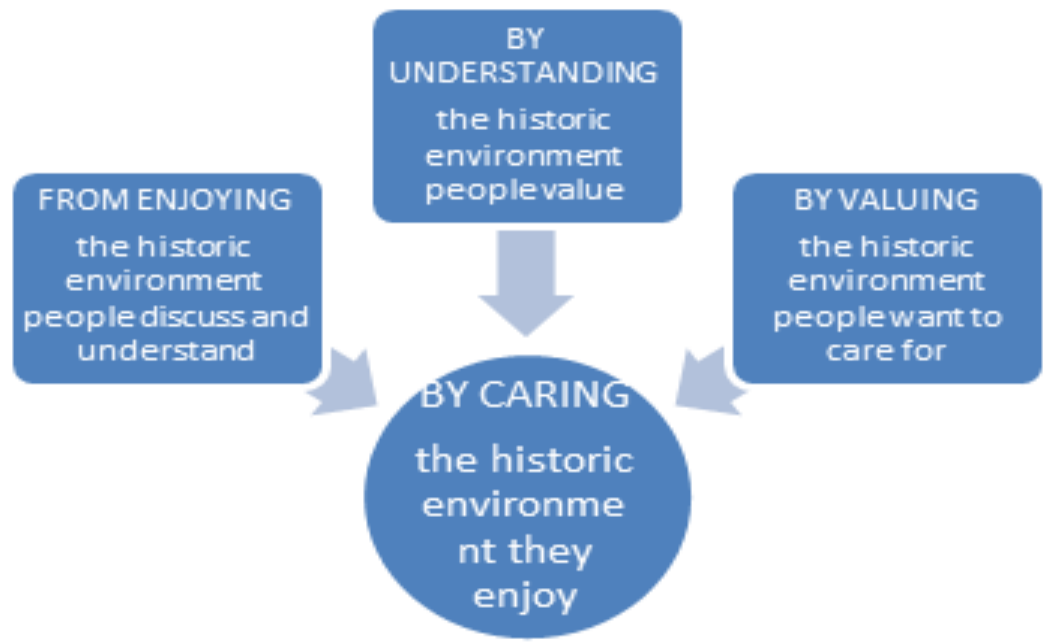

\subsection{Influence of Cultural Heritage Assets on Urban Morphology}

It is culture that generated the development of the socio-economic, technical and political structure of empire-building, that formed various social groups, which in turn shaped their built environment. Stephenson et al. (2004) opined that key heritage impact comprises cultural perceptions and traditions, historic importance and value for providing information about the past and shared meaning to community members. From their study, it was revealed that people are unlikely to protect places unless they comprehend why they are important. Bramwell \& Lane, (1993) revealed that social uprightness values are frequently disturbed when cultural heritage values are separated or demolished by construction, redevelopment, and overuse of heritage assets. Rapoport (1977) claimed that environmental settings act as an expression of culture, values, activities and relative status. He stated that "communal aspects of the city are often judged through the measuring of physical elements, which are unique and symbolic." Freeman (1984) opined that "buildings give meaning through their connotation in history. "He based his statement on the fact that "the image of a place beyond the normal reality to the more mental linking with human history and life is how a conscious sense of place is created and strengthened in a community." Rossi (1982) emphasized that urban morphology is a source of culture from the past and for the future. The long-time span of culture qualifies it as a heritage. Culture extents from the past through the present into the indefinite future. Stephenson et al. (2004) distinguished that vital heritage worth comprises cultural insights and traditions, historic reputation and value for providing information about the past and shared meaning to communal members. Ahmad, (2006) mentioned culture as the total intricate of diverse mystical, logical, emotional and material features that distinguish a particular society and its way of life. Settlements are specifically located on the earth surface where human habitants are formed. Settlements 
are vital in every area of life since it is through their development that man can explore the environment for his needs. Some factors affect setting and distribution of settlements over space. These factors are; relief, climate, vegetation, political, socio-economic, historic and mythical origin Anifowose T. (2020).

\section{Methodology}

This research defined morphology, the importance of cultural heritage assets and the formation of EgbaAke town. This study was conducted using a qualitative method. In-depth interviews and personal observation was used for data collection. The transcribed interviews were presented in Nvivo words tree and satellite imagery was used to analyze collected data.

\section{Summary of Findings and Discussions}

Egba-Ake town has a very distinct history, the town has some cultural heritage assets, either tangible or intangible that are located in Ake's palace in relation to the town formation. Ake's palace is a traditional square and the official residence of the Alake of Egba-Ake paramount ruler. Ake's palace and Itoku market house a lot of cultural heritage, especially inherited objects as important elements surrounded by other supporting elements. This study signified essential cultural assets and cultural activities that took place in the palace square. Important cultural heritage that is valued by the people to buildings and cultural activities like religion were explored in relation to the town formation. Egba-Ake evolved from the palace square in Yoruba Agbo-ile hierarchy order.

\subsection{Egba-Ake Cultural Heritage Assets}

Cultural heritage assets or cultural attributes of the community were considered on architectural design element, historic discernment and cultural activities of the traditional square, historical antecedent of the traditional square as well as the major activity of the community. The traditional squares are used for various activities namely political activities, economic activities, religious activities and social activities. Ake's palace in Egba-Ake town, Abeokuta is the main destination for tourists visiting Ake town because it is an integral part of culture-based sight-seeing in the town. Alake's Palace preserves various aspects of Egba cultural heritage, including physical goods and local art. The Palace has a different management system than other tourism destinations because it is also the official residence of the Alake of Egba-Ake paramount ruler. The palace is captured with architectural distinctive buildings. The square comprised religious buildings, a museum as well as a public square. Ake's palace has a celebrated entrance that connects to a major route that leads to the palace square where festivals and events take place within the square as shown in figure 4 below. The museum housed ancient artifacts. Centenary Hall figure 5 and St. 
Peters Cathedral Church Ake figure 4 which is the first church in the community overlook the traditional square. Below is figure 4 showing the Nvivo word cloud of Ake's traditional square character.

Figure 3: Ake's traditional square character

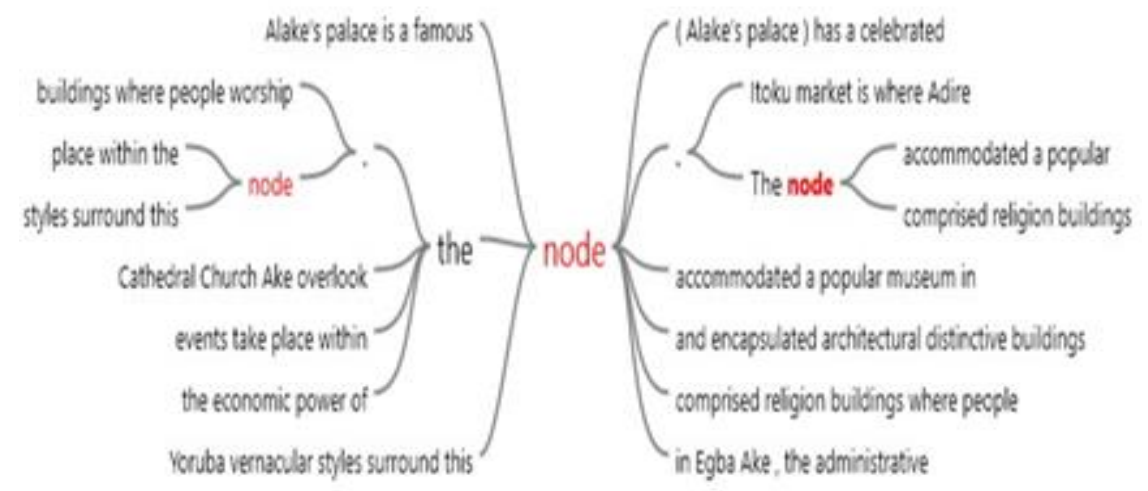

Figure 4: St. Peter's Cathedral Church Ake

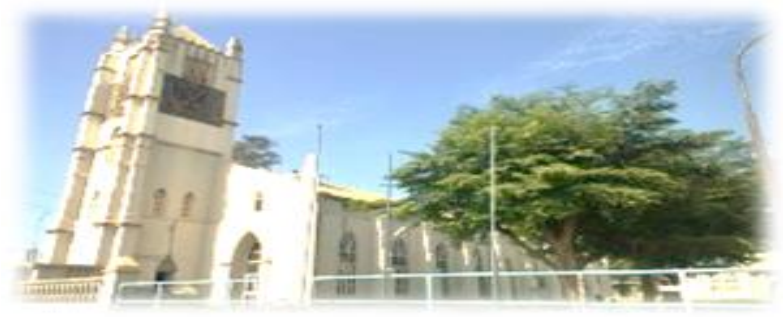

Figure 5: Centenary hall, Ake

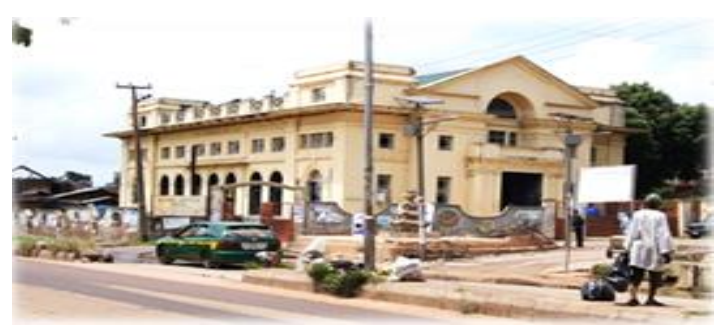

The palace is the administrative organ of the town, which is the center of development around which the Egba Ake community evolved, it encompassed the ancient museum (idi ere or Dipomu) and religious centers within which the city functioned and developed as well as the public square for all activities. Ake's palace is the seat of the paramount ruler of Egbaland, as the rightful ownership of Itoku market which is the economic hub that drives the entire town that is identified with famous tie and dye fabrics called Adire in the native parlance.

\subsection{Egba Ake's Cultural Activities}

There is a chapel within the palace where Christians gathered together to worship as well as a Mosque where Muslims congregated to observe daily prayers and lyamode temple within the palace where the Ogboni worship their deities as shown in figure below. It was gathered that 40 percent of the population were Christians and Muslims each while the remaining 20 percent were of Africa traditional belief. The square was a symbol of unity for the people as the palace served as an administrative organ for the community, it also served as religious and social center for the town; the palace square is used for various festivals and events such as new yam called Ela festival which is a cultural activity that takes place in the palace square yearly. On the other hand, Itoku market served as economic power for the town identified 
with the sales of tie and dye fabrics known as Adire fabrics and local herbs for treatment of different ailments.

Figure 6 showing heritage places of religious activities in Ake's palace
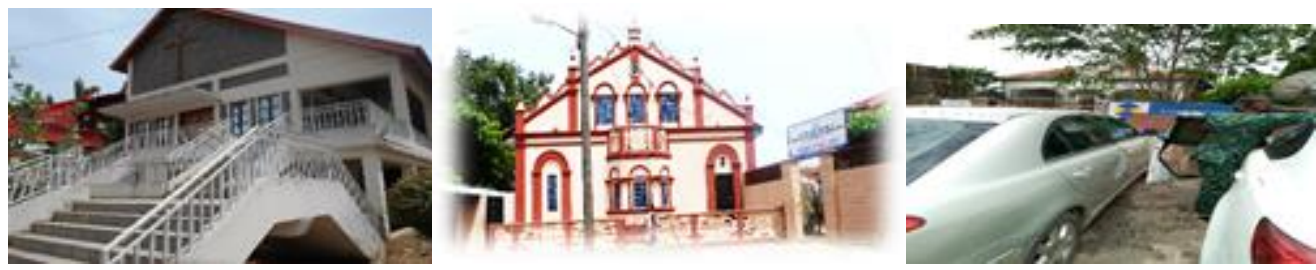

\subsection{Morphology of Egba-Ake}

Egba-Ake town was situated on low land with a nucleated pattern of settlement. The Ake's square is located at the center around which the community evolved. The urban tissue of the community is arranged in hierarchical order from planned square to organic winding lanes that terminate in quenching courtyard (Ebi courtyards). The city parades many places of cultural interest because of the abundance of natural artistic talents and natural landscapes like River Ogun and Oyan River. These includes the Olumo-Rock Heritage Site, Olufunmilayo Ransome Kuti house, Ake's palace Museum, the Alake old and new palaces under study, Mosaic art, beads, painting, carving, Batik and Tie-dyeing traditional cloth making in Itoku Market and other artworks are abundant in Egba-Ake the buildings evolved for social, economic and defensive reasons. The settlement's pattern synthesis is organic and grows around Ake traditional square, cross roads, pathways and at " $\mathrm{T}$ " junctions. Ancient museums and religious centers dominate the square. The inhabitants make the decision on what to do with the resources around them, especially rock terminals and water bodies. The people created interaction and relationships governed by social artifacts especially economic, cultural, political and spiritual feelings. The networks are channels through which people, energy, and information flow. The king's palace and market are centrally situated in the town. Itoku market is popular noted for Adire fabric (tie and dye) as it is called in native parlance as given universal recognition to the town as its economic heritage. The abundance of rivers such as Ogun, Oyan made possible the production of Adire fabric as it requires a lot of water for its production. Figure 7 showing satellite imagery of Egba-Ake 


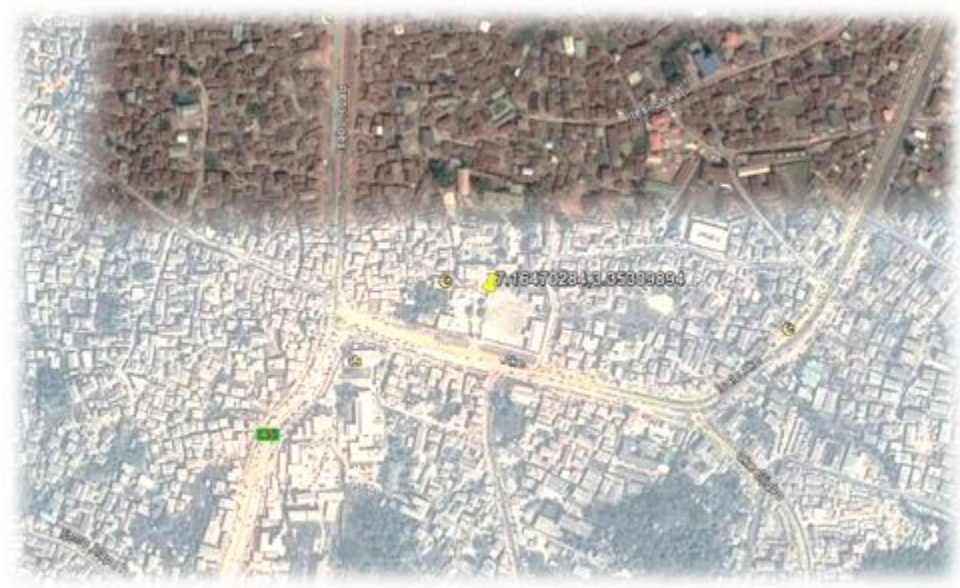

Figure 7 showing satellite imagery of Egba-Ake

\section{4 Conclusion}

Findings in this study highlighted tangible cultural heritage assets and cultural activities treasure by EgbaAke people today that was also valued by the past generations. This study revealed the connecting element between Egba-Ake environment, cultural values and the community morphology. Cultural features gleaned from history contribute to the vitality and robustness of the community; cultural assets lend a sense of history and belongingness to the descendants of the past generations. This study shows that cultural assets consist of expressive, religious and immaterial elements. It can be something physical material such as a meeting place like palace square, market and religious place of worship and it can also be a unique way such as a path or alley which encourages special types of activities and contributes to the unique ambiance of the town. Egba-Ake communities tend to honor the formation of their town by celebrating it through cultural activities and religious events. History of cultural heritage approaches of Egba-Ake demonstrated how different periods, social conditions and ideologies, etc., had affected the current perception of the past values.

However, the same relics that are considered valuable for a society in a specific period might not necessarily be important or precious for another or same society in any period of time. The importance of cultural heritage is not related to a group of people in a specific geographic location, but it means all cultural significance belonging to different cultures in different geographic locations of the world. In fact, to give an international character to our cultural heritage, it would be valuable, as a part of whole, to name them "World Cultural Heritage". World Cultural Heritage can create connections between different social values, 
beliefs, religions, histories and customs. They can also provide conditions to share our mindsets and historic backgrounds with others throughout the world. In this process, the world cultural heritage forms a veritable sense of unity and belonging within a group and opens a new avenue to know ourselves. Finally, cultural heritage assets function as an indicator background that include Egba-Ake processes in the modern city's planning and reconciled Egba-Ake urban multidimensional functions and development.

\section{References}

Abdel Tawab, A. G. (2014). The World Heritage Centre's approaches to the conservation of New Gourna Village, and the assessment of its authenticity and integrity. Alexandria Engineering Journal, 53(3), 691704. http://doi.org/10.1016/j.aej.2014.01.010

Adedimeji, M. A. (2009). Globalization and the survival of the Nigerian cultural and linguistic heritage: The American paradigm. In Adeyanju, D. (Ed.).

Ahmad AG (2006). Cultural heritage of Southeast Asia: preservation for world recognition. J. Malaysian Town Plan, 3(1): 52-62.

Anifowose, T. (2020). Study of Product Branding Morphology at Abeokuta urban communities of Ogun state, Nigeria. International Journal of Advances in Scientific Research and Engineering (ijasre), 6(4), DOI:10.31695/IJASRE.2020.33781

Aplin, G. (2002). Heritage, identification, conservation and management. United Kingdom: Oxford University Press.

Bramwell, W.M. and Lane, B. (1993) Sustainable tourism: An evolving global approach Journal of Sustainable Tourism 1(1) 1-5

Davison, G. (1991) 'The meaning of heritage'. In G. Davison and C. McConville (eds.) A heritage handbook. Allen \& Unwin, St Leonards, NSW. pp. 1-13.

Edo V.O (2005)" Concepts of Culture and Civilization" in Oguntomisin G.O and Edo V.O (Eds) African Culture and Civilization, Ibadan: GSP, University of Ibadan.

Fallahi, A. 2008. An interdisciplinary analytical study on the risk preparedness of Bam and its cultural landscape, a world heritage property in danger in Iran, The Australian Journal of Emergency Management, 23(2): 20-29.

Famuyiwa, J. (1992). The Role of Traditional Festivals and modern Festivals of Arts and Culture in the promotion of Cultural education in Nigeria Nigerian Heritage: Journal of the National Commissionfor Museums and Monuments, Vol. 1

Feather, J. 2006. Managing the documentary heritage: issues for the present and future. In: Gorman, G.E. and Sydney J. Shep. (eds.), Preservation management for libraries, archives and museums. London: Facet, pp. 1-18.

Freeman H (1984) (ed.). Mental health and environment. Great Britain: Churchill LivingStone.

Griffiths, R. (2006). City/culture discourses: Evidence from the competition to select the European Capital of Culture 2008. European Planning Studies, 14(4), 415-430. 
Howard, P. (2003) Heritage: Management, interpretation, identity. Continuum, London.

Hutt, S., C. Blanco and O. Varmer (1999) Heritage resources law: Protecting the archaeological and cultural environment. Wiley, New York.

Idowu, E.B. (1970). Olodumare: God in Yoruba belief London: Longman.

Jokilehto, J. 1986. A History of Architectural Conservation: The Contribution Of English, French, German And Italian Thought Towards An International Approach To The Conservation Of Cultural Property (D.Phil. Thesis, The University Of York, Institute of advanced Architectural Studies, England.

Madden, D. J. (2012). Cities Full of Symbols: A Theory of Urban Space and Culture. (P. J. M. Nas, Ed.). Leiden, NL: Leiden University Press.

Ogundele, S. O. (2014). Understanding Contemporary Archaeology.Ibadan, John Archers Publishers Limited.

Ogungbile, D. (1998). Islam and Cultural Identity in Nigeria: The Osogbo-Yoruba Orita Ibadan Journal of Religious Studies, Vol. Xxx/1-2, June \& December 1998.

O"Neil, D. (2006). What is Culture? Retrieved October 20, 2015, from http://anthro.palomar.edu/culture/culture_1.htm

Pearson, M. and S. Sullivan (1995) Looking after heritage places: the basics of heritage planning for managers, landowners and administrators. Melbourne University Press, Melbourne, VIC.

Pejovic, K. (2009). Urban arts festivals: A mark on regions. In A.M. Autissier (Ed.), The Europe of festivals: From Zagreb to Edinburgh, interesting viewpoints ... (63-73). Toulouse/Paris: Edition de l'attribut and Culture Europe International.

Rapoport A (1977). Human aspects of urban form: Towards a man-environment approach to urban form and design. Oxford: Pergamon Press, pp. 317-322.

Shin, H. (2004). Cultural festivals and regional identities in South Korea. Environment and Planning D: Society and Space, 22, 619-632.

Stephenson J, Bauchop H, Petchey P (2004). Bannockburn heritage landscape study. New Zealand: Department of Conservation.

Thurley, S. 2005. Into the future. Our strategy for 2005-2010. In: Conservation Bulletin [English Heritage] (49).

Yardimci, S. (2007). Festivalising difference: Privatisation of culture and symbolic exclusion in Istanbul (EUI Working Papers RSCAS 2007/35). Florence: EUI

\section{Author's Profile}




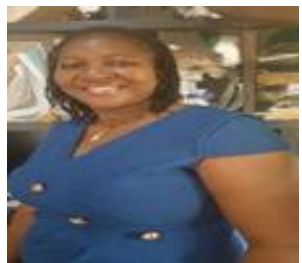

Anifowose Titilayo received Bachelor and Master's degree in architecture from Abia state university, Uturu in 2003 and 2006 respectively. She practiced in the construction industry for many years before joining Bell University of Technology in Ota, Ogun state Nigeria in 2020. She teaches research methodology in the department of architecture Bell University of Technology Ota. Anifowose Titilayo is doing her PhD in University of Lagos Akoka where her focus is in place-making (city branding through urban morphology). She is a member of the international society of city and regional planners (ISOCARP). Recently, her research involves place-making and experience design with socio-cultural aspects. 